\title{
PENGARUH PEMBELAJARAN BERPENDEKATAN SAINTIFIK BERORIENTASI TRI HITA KARANA TERHADAP KOMPETENSI PENGETAHUAN IPS SISWA KELAS IV
}

\author{
${ }^{1}$ Km. Krisna Handayani, ${ }^{2}$ Ign. I Wayan Suwatra, ${ }^{3}$ D. Putu Parmiti \\ ${ }^{1} J u r u s a n$ Pendidian Dasar, Universitas Pendidikan Ganesha, Singaraja, Indonesia \\ 2,3 Jurusan IImu Pendidikan, Psikologi, Bimbingan, Universitas Pendidikan Ganesha, \\ Singaraja, Indonesia \\ email: \{krisna,handayani, ignatiusiwayan.suwatra, dp-parmiti\}@undiksha.ac.id
}

\begin{abstract}
Abstrak
Pembelajaran IPS di sekolah dasar masih bersifat membosankan bagi siswa, sehingga membuat siswa tidak fokus dan tidak tertarik untuk mengikuti proses pembelajaran. Hal tersebut dibuktikan dengan banyaknya nilai IPS siswa yang masih berada di bawah KKM. Penelitian ini bertujuan untuk mengetahui pengaruh pembelajaran berpendekatan saintifik berorientasi Tri Hita Karana terhadap kompetensi pengetahuan IPS siswa SD kelas IV di Gugus II Kecamatan Bangli Kabupaten Bangli. Jenis penelitian yang digunakan adalah Quasi Eksperiment. Populasi dalam penelitian ini adalah siswa kelas IV semester II Gugus II kecamatan Bangli Kabupaten Bangli yang berjumlah 165 orang siswa. Sampel sebanyak 46 orang siswa. Data dikumpulkan menggunakan instrument tes objektif. Analisis data yang digunakan dalam penelitian ini adalah ANAVA. Berdasarkan penelitian yang telah dilakukan diperoleh dari kelas eksperimen bahwa kompetensi pengetahuan IPS siswa tergolong sangat tinggi dengan nilai rata-rata 79,2. Sedangkan pada kelas kontrol diperoleh bahwa kompetensi pengetahuan IPS siswa tergolong tinggi dengan rata-rata sebesar 64 . Hasil uji hipotesis menunjukkan bahwa nilai signifikansi $5 \% t_{\text {hitung }}=43,44>t_{\text {tabel }}=1,68023$ yang berarti terdapat pengaruh pembelajaran berpendekatan saintifik berorientasi Tri Hita Karana terhadap kompetensi pengetahuan IPS siswa SD. Dari hasil temuan diatas dapat disimpulkan bahwa terdapat pengaruh pengaruh pembelajaran berpendekatan saintifik berorientasi Tri Hita Karana terhadap kompetensi pengetahuan IPS siswa kelas IV semester II SD Gugus II Kecamatan Bangli.
\end{abstract}

Kata-kata kunci : Kompetensi pengetahuan IPS, Saintifik, Tri Hita Karana

\begin{abstract}
Social studies learning in elementary schools is still boring for students, making students out of focus and not interested in participating in the learning process. This is evidenced by the many grades of social studies students who are still under the KKM. This study aims to determine the effect of learning oriented scientific oriented Tri Hita Karana on the competency of social science knowledge of fourth grade elementary school students in Cluster II Bangli Subdistrict Bangli Regency Academic Year 2018/2019. The type of research used is Quasi Experiment. The population in this study were class IV semester II of Class II in Bangli sub-district, Bangli Regency, which amounted to 165 students. A sample of 46 students. Data was collected using objective test instruments. The data analysis used in this study is ANOVA. Based on the research that has been done, it was obtained from the experimental class that students' social science knowledge competencies were very high with an average value of 79.2. Whereas in the control class it was found that the students' IPS knowledge competency was classified as high with an average of 64 . The results of the
\end{abstract}


Km. Krisna Handayani, Ign. I Wayan Suwatra, D. Putu Parmiti. (2018). Jurnal Pendidikan Multikultural Indonesia. Vol. 1 (2) pp. 85-95.

hypothesis test showed that the significance value was $5 \%$ tcount $=43.44>t$ table $=1.68023$ which means there was an effect of learning oriented scientific orientation Tri Hita Karana to the social science competency of elementary school students. From the results of the above findings it can be concluded that there is an influence of the influence of learning with scientific approach oriented to Tri Hita Karana on the competency of social science knowledge of class II semester II SD Group II Bangli District Academic Year 2018/2019.

Keywords: IPS knowledge competency, scientific approach, Tri Hita Karana

\section{PENDAHULUAN}

Pendidikan merupakan unsur yang sangat penting bagi setiap manusia, karena pendidikan merupakan kewajiban yang berlaku sepanjang hayat. Selain dapat menguasai ilmu pengetahuan, pendidikan dapat menjadikan manusia memiliki kemampuan berpikir logis, bersikap kritis, unggul berinisiatif dan kompetitif. Sutoyo (2011:2) menyatakan bahwa,

Pendidikan pada hakikatnya adalah usaha sadar dan berencana untuk mewujudkan proses pembelajaran agar peserta didik secara aktif mengembangkan potensi dirinya untuk memiliki kekuatan spiritual keagamaan, pengendalian diri, kepribadian, kecerdasan, akhlak mulia serta keterampilan yang diperlukan dirinya, masyarakat, bangsa, dan negara.

Dari penjelasan diatas dapat diketahui bahwa dengan melaksanakan pendidikan peserta didik dapat mengembangkan potensi yang dimilikinya. Pendidikan pada jenjang SD diselenggarakan dengan tujuan untuk mengembangkan kemampuan dan keterampilan dasar yang diperlukan untuk hidup dan bermasyarakat. Jadi tujuan pendidikan yaitu untuk mengembangkan potensi yang dimiliki oleh manusia sehingga menjadi manusia yang lebih baik lagi baik dalam sikap, pengetahuan, maupun keterampilan yang dimilikinya. Salah satu usaha pemerintah untuk memperbaiki kualitas mutu pendidikan agar dapat mencetak manusia yang berkualitas adalah dengan memperbaiki kurikulum. Kurikulum didefinisikan sebagai seperangkat rencana dan pengaturan mengenai tujuan, isi, dan bahan pelajaran serta cara yang digunakan sebagai pedoman penyelenggaraan kegiatan pembelajaran untuk mencapai tujuan pendidikan tertentu.

Kurikulum 2013 merupakan penyempurnaan dari kurikulum sebelumnya yaitu kurikulum KTSP. Menurut Priyanti (2016) kurikulum merupakan pedoman dalam penyelenggaraan kegiatan pembelajaran. Dimana kurikulum 2013 SD menggunakan pembelajaran tematik integratif. Pembelajaran tematik integratif merupakan pembelajaran yang memadukan berbagai kompetensi dari berbagai mata pelajaran kedalam berbagai tema (Megawati, 2015). Dengan begitu siswa akan memperoleh pengetahuan yang lebih luas sehingga pembelajaran menjadi lebih bermakna. Proses pembelajaran dalam kurikulum 2013 dilaksanakan dengan menggunakan pendekatan saintifik. Menurut Widariwati (2016) setiap pelajaran dalam kurikulum 2013 mengarahkan siswa untuk membangun pengetahuannya sendiri yang mana dengan hal tersebut akan berdampak baik terhadap hasil belajar siswa. Penerapan kurikulum 2013 diharapkan dapat meningkatkan kualitas pendidikan di Indonesia. Keberhasilan dalam pendidikan merupakan sesuatu yang sangat diharapkan bagi setiap manusia, seperti keberhasilan dalam proses belajar mengajar di sekolah.

Untuk mencapai keberhasilan dalam proses belajar tentunya melibatkan beberapa peran yaitu peran guru sebagai pengajar dan peran siswa sebagai peserta belajar. Peran guru sangat penting dalam proses belajar mengajar. Seorang guru harus dapat mengontrol kelasnya saat proses pembelajaran berlangsung karena gurulah yang mengetahui sifat dan 
Km. Krisna Handayani, Ign. I Wayan Suwatra, D. Putu Parmiti. (2018). Jurnal Pendidikan Multikultural Indonesia. Vol. 1 (2) pp. 85-95.

karakter tiap siswa di kelasnya agar proses belajar berjalan dengan lancar. Seseorang yang berusaha memiliki pengetahuan atau kecakapan disebut belajar. Setelah melakukan proses belajar maka akan terjadi perubahan atau peningkatan pengetahuan pada diri manusia. Jadi belajar merupakan perubahan dalam kepribadian diri manusia menuju arah yang lebih baik.

Dalam proses pembelajaran di sekolah terdapat beberapa mata pelajaran yang harus dikuasai oleh siswa, salah satunya yaitu mata pelajaran IPS. Menurut Susanto (2013:138) "Hakikat IPS di sekolah dasar memberikan pengetahuan dasar dan keterampilan sebagai media pelatihan bagi siswa sebagai warga negara sedini mungkin". Pengajaran IPS sangat penting bagi jenjang pendidikan dasar karena siswa yang datang ke sekolah berasal dari lingkungan yang berbeda-beda. Proses pembelajaran IPS di sekolah dasar guru perlu memperhatikan karakteristik siswa yang senang belajar atau bekerjasama dalam kelompok, senang bermain-main, dan senang merasakan atau ikut serta dalam melakukan sesuatu secara langsung, sehingga tujuan pembelajaran yang diharapkan akan tercapai sesuai harapan karena pembelajaran IPS harus dikuasai dan dipahami dengan baik. Adiwiguna (2016) menyatakan bahwa "Pembelajaran materi IPS di sekolah dasar menekankan pada pemberian pengalaman langsung untuk mengembangkan kompetensi agar siswa dapat menjelajahi dan memahami manusia dan sejumlah aktivitasnya".

Tujuan mempelajari IPS yaitu untuk mengembangkan kemampuan dalam lingkungannya. Menutut Murda dan Yudiana (2016:16) tujuan pendidikan IPS di sekolah adalah "membina anak didik menjadi warga negara yang baik, yang memiliki pengetahuan, keterampilan dan kepedulian sosial yang berguna bagi dirinya sendiri serta bagi masyarakat dan negara". Selain itu Trianto (2010:176) menyatakan bahwa,

Tujuan utama Ilmu Pengetahuan Sosial ialah untuk mengembangkan potensi peserta didik agar peka terhadap masalah sosial yang terjadi di masyarakat, memiliki mental positif terhadap perbaikan segala kepentingan yang terjadi, dan terampil mengatasi setiap masalah terjadi sehari-hari, baik yang menimpa dirinya sendiri maupun yang menimpa masyarakat.

Jadi dapat disimpulkan bahwa tujuan pembelajaran IPS adalah untuk membina dan mengembangkan potensi peserta didik agar memiliki pengetahuan, keterampilan dan kepedulian sosial yang berguna bagi dirinya sendiri serta bagi masyarakat dan negara, memiliki mental positif terhadap perbaikan segala kepentingan yang terjadi, dan terampil mengatasi setiap masalah terjadi sehari-hari, baik yang menimpa dirinya sendiri maupun yang menimpa masyarakat.Pembelajaran IPS di sekolah dasar selalu dikaitkan dengan kegiatan siswa dalam kehidupan sehari-hari. Pelaksanaan pembelajaran yang seperti ini menyenangkan dan bermakna bagi siswa. Pelaksanaan pembelajaran yang menyenangkan akan memacu hasil belajar IPS siswa.

Kenyataan di lapangan tidak seperti yang diharapkan Pembelajaran IPS di sekolah dasar belum optimal, hal ini dikarenakan guru kurang memanfaatkan lingkungan sosial dan lingkungan di sekitar siswa sebagai sumber belajar. Pembelajaran yang seperti ini akan membuat siswa merasa bahwa apa yang telah dipelajari kurang bermakna bagi kehidupannya. Jika pembelajaran ini terus diterapkan maka akan menimbulkan kejenuhan pada siswa dan nantinya akan mempengaruhi hasil belajar siswa.

Berdasarkan hasil observasi awal yang dilakukan pada tanggal 17 Desember 2018 dan 10 Januari 2019 di kelas IV SD Gugus II Kecamatan Bangli diperoleh data bahwa kompetensi pengetahuan IPS siswa kelas IV masih banyak yang berada di bawah kriteria ketuntasan minimal (KKM). Ini dibuktikan dengan daftar hasil UAS pada mata pelajaran IPS siswa kelas IV SDN Gugus II Kecamatan Bangli Kabupaten Bangli. 
Km. Krisna Handayani, Ign. I Wayan Suwatra, D. Putu Parmiti. (2018). Jurnal Pendidikan Multikultural Indonesia. Vol. 1 (2) pp. 85-95.

Tabel 1. Daftar Rata-rata Nilai Mata Pelajaran IPS Siswa Kelas IV SDN Gugus II Kecamatan Bangli

\begin{tabular}{lllll}
\hline No. & Sekolah & Nilai KKM & Jumlah Siswa & Rata-Rata \\
\hline 1 & SD Negeri 2 Kawan & 75 & 28 siswa & 72,90 \\
\hline 2 & SD Negeri 3 Kawan & 73 & 38 siswa & 68,34 \\
\hline 3 & SD Negeri 5 Kawan & 74 & 31 siswa & 70,23 \\
\hline 4 & SD Negeri 1 Bebalang & 67 & 22 siswa & 66,91 \\
\hline 5 & SD Negeri 2 Bebalang & 67 & 26 siswa & 68,58 \\
\hline 6 & SD Negeri 3 Bebalang & 65 & 20 siswa & 66,40 \\
\hline
\end{tabular}

Data pada Tabel 1 di atas memperlihatkan bahwa kompetensi pengetahuan IPS siswa masih rendah, sehingga belum memenuhi Kriteria Ketuntasan Minimal (KKM). Kenyataan ini memberikan dorongan bagi para pendidik untuk memperbaiki dan meningkatkan kualitas pendidikan IPS agar tujuan dari pembelajaran IPS dapat tercapai dengan optimal dan kompetensi pengetahuan siswa meningkat. Untuk meningkatkan kompetensi pengetahuan siswa diperlukan pembelajaran yang menarik dan menyenangkan. Pembelajaran menjadi menarik dan menyenangkan apabila seorang guru dapat menciptakan pembelajaran yang nyata berkaitan dengan siswa. Dalam proses pembelajaran guru harus melibatkan siswa secara langsung, sehingga siswa dapat mengembangkan segala kreativitas dan pengetahuan yang dimilikinya untuk dibawa kearah yang positif sehingga hasil belajar dapat tercapai secara optimal. Salah satu solusi yang dapat dilakukan untuk membuat siswa lebih tertarik dan semangat saat mengikuti pembelajaran yaitu dengan menerapkan pembelajaran menggunakan pendekatan saintifik berorientasi Tri Hita Karana. Kita ketahui bahwa kurikulum 2013 saat ini menggunakan pendekatan saintifik dalam proses pembelajaran. Pendekatan saintifik merupakan pendekatan pembelajaran yang mengutamakan temuan siswa sehingga siswa aktif dan kreatif membangun konsep dan prinsip melalui peristiwa mengamati, menanya, mengumpulkan informasi/melakukan eksperimen, mengasosiasikan/mengolah informasi, dan mengomunikasikan. Menurut Ardiantari (2015) pendekatan saintifik yang menekankan analisis tentang proses berpikir dan memupuk kemampuan berpikir serta pemahaman siswa. pendekatan ini akan lebih sempurna lagi apabila diorientasikan dengan Tri Hita Karana.

Tri Hita Karana berasal dari kata Tri artinya tiga, Hita artinya bahagia, dan Karana artinya penyebab. Jadi Tri Hita Karana berarti tiga penyebab kebahagiaan. Adapun penyebab kebahagiaan yaitu dengan mengupayakan hubungan yang harmonis antara manusia dengan Tuhan, dengan sesama manusia, dan dengan lingkungan sekitar (alam). Putra (2016) menyatakan bahwa.

Dengan menerapkan tiga bagian dari Tri Hita Karana yang pertama yaitu Parhyangan, siswa akan terbiasa untuk berdoa sebelum dan sesudah pembelajaran berlangsung, kedua yaitu Pawongan, siswa akan terbiasa untuk saling menghargai pendapat dan perbedaan dengan temannya sehingga suasana kelas menjadi harmonis, dan yang ketiga Palemahan, siswa akan terbiasa untuk memanfaatkan lingkungannya dengan bijak dan menjaga lingkungannya supaya tetap asri dan lestari.

Tiga penyebab kebahagiaan yang dimaksud yaitu:

1. Hubungan yang baik antara manusia dengan Tuhan yang Maha Esa

Manusia merupakan ciptahan Tuhan, oleh karena itu manusia wajib berterimakasih, berbakti, dan selalu bersujud kepada Tuhan Yang Maha Esa. Rasa terimakasih dapat 
Km. Krisna Handayani, Ign. I Wayan Suwatra, D. Putu Parmiti. (2018). Jurnal Pendidikan Multikultural Indonesia. Vol. 1 (2) pp. 85-95.

disajikan dalam bentuk puja dan puji syukur terhadap kebesaranNya, seperti dengan sembahyang setiap hari, melaksanakan yadnya, dan mengamalkan ajaran agama.

2. Hubungan yang baik antara sesama manusia

Manusia sebagai makhluk sosial tidak dapat hidup sendiri, melainkan memerlukan bantuan orang lain. Oleh karena itu hubungan antar sesame manusia harus dijaga agar tetap harmonis. Hubungan antar manusia harus diatur dengan dasar saling asah, asih, dan asuh serta saling membimbing satu sama lain. Hubungan yang bai kantar manusia akan menciptakan kesejahteraan dan kedamaian lahir batin di masyarakat

3. Hubungan yang baik antara manusia dengan lingkungan (alam)

Manusia hidup di lingkungan tertentu. Manusia banyak mendapatkan makanan dan kebutuhan lainnya dari lingkungan. Dengan demikian manusia sangat bergantung pada lingkungan. Oleh karena itu manusia harus memperhatikan, memelihara, dan menjaga lingkungannya. Seperti hutan tidak boleh ditebang sembarangan dan hewan tidak boleh diburu seenaknya, karena dapat mengganggu keseimbangan alam. Maka dari itu lingkungan yang dijaga dan ditata dengan baik akan menciptakan rasa tenang dan damai dalam diri manusia.

Jadi, pendekatan saintifik berorientasi Tri Hita Karana merupakan pendekatan pembelajaran yang lebih mementingkan penemuan siswa dimana siswa dituntut untuk lebih aktif dalam proses pembelajaran dan mengaitkan pembelajaran dengan contoh-contoh nyata menjalin hubungan harmonis dengan tuhan, sesama manusia, dan dengan lingkungannya, sehingga pembelajaran menjadi lebih nyata dan menarik bagi siswa. Dengan menerapkan pendekatan saintifik berorientasi Tri Hita Karana guru dapat mengaitkan pelajaran dengan lingkungan sekitar siswa dan membuat siswa ikut berperan aktif dalam proses pembelajaran. Apabila siswa sudah dapat berperan aktif saat proses pembelajaran maka kompetensi pengetahuan siswa akan meningkat.

\section{METODE}

Penelitian ini dilaksanakan di kelas IV SD Gugus II Kecamatan Bangli yang terdiri dari SD Negeri 2 Kawan, SD Negeri 3 Kawan, SD Negeri 5 Kawan, SD Negeri 1 Bebalang, SD Negeri 2 Bebalang, dan SD Negeri 3 Bebalang. Dalam pelaksanaannya, penelitian ini dilaksanakan di kelas eksperimen dan kelas kontrol yang sudah diuji kesetaraannya.

Penelitian ini dilaksanakan selama 2 bulan, yaitu mulai bulan April sampai bulan Mei 2019. Penelitian dilaksanakan di dua SD yang berada di Gugus II Kecamatan Bangli. Sampel dalam penelitian ini yaitu SD Negeri 2 Bebalang sebagai kelompok eksperimen dan SD Negeri 3 Bebalang sebagai kelompok kontrol.

Penelitian ini merupakan sebuah penelitian eksperimen. Desain penelitian ini adalah desain kuasi eksperimen (quasy experiment) dengan alasan karena tidak semua variabel dapat dikontrol secara ketat seperti mengontrol variabel-variabel di luar yang mempengaruhi pelaksanaan selama eksperimen eksperimen berlangsung. Dalam kuasai eksperimen melibatkan dua kelompok kelas yaitu kelas eksperimen dan kelas kontrol. Kelompok eksperimen diberikan pembelajaran dengan menggunakan pendekatan saintifik berorientasi Tri Hita Karana, sedangkan kelompok kontrol diberikan pembelajaran dengan menggunakan pendekatan saintifik. Penelitian ini menggunakan rancangan Non Equivalent Post-Test Only Control Group Design dengan desain seperti pada Tabel 2. 
Km. Krisna Handayani, Ign. I Wayan Suwatra, D. Putu Parmiti. (2018). Jurnal Pendidikan Multikultural Indonesia. Vol. 1 (2) pp. 85-95.

Tabel 2. Non Equivalent Post-Test Only Control Group Design

\begin{tabular}{lll}
\hline Kelompok & Perlakuan & Post-Test \\
\hline Eksperimen $(\mathrm{E})$ & $\mathrm{X}$ & $\mathrm{O}_{1}$ \\
\hline Kontrol (K) & - & $\mathrm{O}_{2}$ \\
\hline
\end{tabular}

Populasi dalam penelitian ini adalah seluruh sekolah di SD Gugus II Kecamatan Bangli yang terdiri dari 6 sekolah dan 165 siswa seperti pada Tabel 3.

Tabel 3. Distribusi Populasi Penelitian

\begin{tabular}{lll}
\hline No & Nama Sekolah & Jumlah Siswa \\
\hline 1 & SD Negeri 2 Kawan & 28 \\
\hline 2 & SD Negeri 3 Kawan & 38 \\
\hline 3 & SD Negeri 5 Kawan & 31 \\
\hline 4 & SD Negeri 1 Bebalang & 22 \\
\hline 5 & SD Negeri 2 Bebalang & 26 \\
\hline 6 & SD Negeri 3 Bebalang & 20 \\
\hline \multicolumn{2}{l}{ Jumlah Siswa } & 165 \\
\hline
\end{tabular}

Teknik yang digunakan untuk memilih sampel penelitian yaitu teknik random sampling. Dari keenam SDN yang sudah diuji kesetaraannya, diadakan pengundian untuk memperoleh 2 kelas sampel. 2 kelas sampel yang diperoleh yaitu SDN 2 Bebalang dan SDN 3 Bebalang. Kedua sekolah tersebut diundi kembali untuk menentukan kelas eksperimen dan kelas kontrol. Hasil dari pengundiannya yaitu SDN 2 Bebalang sebagai kelas eksperimen dan SDN 3 Bebalang sebagai kelas kontrol.

Data yang dikumpulkan dalam penelitian ini yaitu data kompetensi pengetahuan IPS siswa. Penelitian ini menggunakan metode tes yang diukur menggunakan instrument tes pilihan ganda yang berjumlah 35 butir soal.

Tes tersebut diberikan pada akhir perlakuan atau post-test kepada kelas sampel untuk menguji hipotesis penelitian. Sebelum instrumen digunakan, item-item instrumen yang sudah disusun berdasarkan kisi-kisi tes terlebih dahulu dikonsultasikan kepada pakar untuk dinilai. Penilaian dilakukan oleh dua pakar. Sebelum dilakukan analisis data terlebih dahulu dilakukan uji prasyarat analisis terhadap data yang diperoleh yaitu uji normalitas sebaran data dan uji homogenitas varians.

Uji normalitas dilakukan untuk mengetahui apakah sebaran data nilai kompetensi pengetahuan IPS siswa masing-masing kelompok berdistribusi normal atau tidak. Kriteria pengujian adalah $x 2 h i t<x 2$ tab pada taraf signifikasi $5 \%$ dengan $\mathrm{dk}=\mathrm{k}-1$, maka $\mathrm{H} 0$ diterima (gagal ditolak) yang berarti data berdistribusi normal. Uji homogenitas varians pada analisis ini digunakan uji $\mathrm{F}$ yaitu varians terbesar dibagi dengan varian terkecil.

Kriteria pengujian adalah jika Fhit $<$ Ftab $(=\mathrm{n} 1-1, \mathrm{n} 2-1)$ maka data memiliki varians yang homogen. Pengujian dilakukan pada taraf signifikansi 5\% dengan derajat kebebasan untuk pembilang $\mathrm{n} 1$ - 1 dan derajat kebebasan untuk penyebut $\mathrm{n} 2-1$. Analisis statistic yang digunakan untuk menguji hipotesis penelitian ini adalah uji-t. 
Km. Krisna Handayani, Ign. I Wayan Suwatra, D. Putu Parmiti. (2018). Jurnal Pendidikan Multikultural Indonesia. Vol. 1 (2) pp. 85-95.

\section{HASIL DAN PEMBAHASAN}

Hasil analisis data diperoleh rata-rata kompetensi pengetahuan IPS kelompok eksperimen dengan pembelajaran berpendekatan saintifik berorientasi Tri Hita Karana adalah 79,2 dengan varian $\left(S^{2}\right)=71,61$ dan Standar Deviasi $(S)=8,46$. Sedangkan nilai rata-rata kompetensi pengetahuan IPS kelompok kontrol dengan pembelajaran saintifik biasa adalah 64 dengan varian $\left(S^{2}\right)=44,46$ dan Standar Deviasi $(S)=6,67$.

Berdasarkan hasil perhitungan menunjukkan bahwa rata-rata kompetensi pengetahuan IPS siswa yang dibelajarkan menggunakan pembelajaran berpendekatan saintifik berorientasi Tri Hita karana lebih tinggi dibandingkan kelompok siswa yang dibelajarkan menggunakan pembelajaran berpendekatan saintifik $(79,2>64)$. Uji normalitas sebaran data kompetensi pengetahuan IPS dengan menggunakan chi-square diperoleh kompetensi pengetahuan IPS kelompok eksperimen adalah 4,05, ini berarti, $x 2$ hit $<x 2$ tab maka ini berarti data kompetensi pengetahuan IPS siswa kelompok eksperimen berdistribusi normal. Sedangkan kompetensi pengetahuan IPS kelompok kontrol adalah 4,94. ini berarti, data kompetensi pengetahuan IPS siswa kelompok kontrol juga berdistribusi normal.

Tabel 4. Hasil Uji Normalitas Sebaran Data Kompetensi Pengetahuan IPS

\begin{tabular}{lllll}
\hline No & $\begin{array}{l}\text { Kelompok Data } \\
\text { Kompetensi } \\
\text { Pengetahuan IPS }\end{array}$ & $X^{2}$ & $\begin{array}{l}\text { Nilai Kritis } \\
\text { pada Taraf } \\
\text { Signifikansi } \\
5 \%\end{array}$ & Status \\
\hline 1 & Eksperimen & 4,05 & 7,815 & Normal \\
\hline 2 & Kontrol & 4,94 & 5,591 & Normal \\
\hline
\end{tabular}

Uji homogenitas varians dilakukan untuk meyakinkan bahwa perbedaan yang terjadi pada uji hipotesis benar-benar terjadi akibat adanya perbedaan antar kelompok, bukan sebagai akibat perbedaan dalam kelompok. Uji Homogenitas varians pada penelitian ini dilakukan dengan uji F. Dari perhitungan diperoleh, Fhit $=1,61$, sedangkan pada Ftab= 2,1057berarti Fhit < Ftab, sehingga kedua kelompok data memiliki varians yang homogen.

Tabel 5. Hasil Uji Homogenitas Kelompok Eksperimen dan Kelompok Kontrol

\begin{tabular}{llll}
\hline $\begin{array}{l}\text { Kelompok Data } \\
\text { Kompetensi }\end{array}$ & F-hitung & $\begin{array}{l}\text { F-tabel dengan } \\
\text { Taraf Signifikansi }\end{array}$ & Status \\
$\begin{array}{l}\text { Pengetahuan IPS } \\
\text { Eksperimen }\end{array}$ & 1,61 & $5 \%$ & \\
\hline Kontrol & & 2,1057 & Homogen \\
\hline
\end{tabular}

Data kompetensi pengetahuan yang telah memenuhi syarat berdistribusi normal dan homogenitas varians selanjutnya diuji hipotesisnya. uji hipotesis dengan menggunakan statistik parametrik yaitu uji-t. Rangkuman hasil analisis uji-t dua kelompok data kompetensi pengetahuan IPS siswa dapat dilihat pada Tabel 6. 
Km. Krisna Handayani, Ign. I Wayan Suwatra, D. Putu Parmiti. (2018). Jurnal Pendidikan Multikultural Indonesia. Vol. 1 (2) pp. 85-95.

Tabel 6. Ringkasan Hasil Uji Hipotesis

\begin{tabular}{|c|c|c|c|c|c|c|}
\hline $\begin{array}{l}\text { Kelompok Data } \\
\text { Kompetensi } \\
\text { Pengetahuan IPS }\end{array}$ & Varians & $\mathrm{N}$ & $\mathrm{Db}$ & $t_{\text {hitung }}$ & $t_{\text {tabel }}$ & kesimpulan \\
\hline Kelompok Eksperimen & 71,61 & 26 & 44 & 43,44 & 1,68023 & $t_{\text {hitung }}>t_{\text {tabel }}$ \\
\hline Kelompok Kontrol & 44,46 & 20 & & & & $\mathrm{H}_{0}$ ditolak \\
\hline
\end{tabular}

Pembahasan hasil penelitian dan pengujian hipotesis menguraikan tentang kompetensi pengetahuan IPS siswa pada ranah kognitif terutama pada pembelajaran Tema 8. Pendekatan saintifik berorientasi Tri Hita Karana yang diterapkan pada kelompok eksperimen dan tidak menggunakannya di kelompok kontrol, dalam penelitian ini menunjukkan pengaruh yang berbeda terhadap kompetensi pengetahuan IPS siswa. Secara deskriptif, kompetensi pengetahuan IPS siswa kelompok eksperimen lebih tinggi dibandingkan dengan siswa kelompok kontrol. Hai ini didasarkan pada rata-rata nilai kompetensi pengetahuan IPS. Kompetensi pengetahuan IPS siswa kelompok eksperimen yaitu 79,2 lebih tinggi dibandingkan kompetensi pengetahuan IPS siswa kelompok kontrol yaitu 64. selain itu, setelah melakukan uji hipotesis diperoleh hasil thitung $=43,44$ dan ttabel $=1,68023$ pada taraf signifikansi $5 \%$ dengan $\mathrm{db}=44$. Ini menunjukkan bahwa thitung $>$ ttabel, sehingga $\mathrm{H} 0$ ditolak dan $\mathrm{H} 1$ diterima. Mengacu pada hasil uji hipotesis, terdapat perbedaan yang signifikan antara kelompok siswa yang dibelajarkan dengan menggunakan pendekatan saintifik berorientasi Tri Hita Karana dengan pendekatan saintifik yang tidak berorientasi Tri Hita Karana terhadap kompetensi pengetahuan IPS siswa kelas IV semester II di gugus II Kecamatan Bangli, Kabupaten Bangli.

Temuan penelitian ini menunjukkan bahwa pendekatan saintifik berorientasi Tri Hita Karana berpengaruh terhadap kompetensi pengetahuan IPS, maka dari itu persoalan diatas disebabkan oleh beberapa hal, yakni.

1. Siswa diajarkan untuk selalu berdoa sebelum memulai dan mengakhiri kegiatan pembelajaran, seperti melaksanakan Puja Tri Sandya sebelum memulai proses pembelajaran dengan menggunakan sarana bunga yang ada di lingkungan sekitar siswa dan berdoa setelah proses pembelajaran berakhir. Guru mengingatkan kepada siswa bahwa kita harus selalu berbakti dan ingat kepada Tuhan

2. Siswa yang menggunakan pendekatan saintifik berorientasi Tri Hita Karana lebih senang dan tertarik untuk mengikuti proses pembelajaran, karena pembelajaran dilaksanakan secara berkelompok sehingga interaksi antara siswa satu dengan siswa lainnya lebih intensif dan mudah untuk berdiskusi, saling bekerjasama, saling membagi ilmu di dalam kelompoknya, belajar untuk menghargai pendapat temannya, serta memberikan tanggapan terhadap kelompok lain.

3. Siswa diajak untuk melihat langsung ke lingkungan di sekitar terkait dengan materi pembelajaran yang akan diajarkan sehingga siswa dapat berinteraksi langsung dengan lingkungan di sekitarnya, dengan demikian pembelajaran menjadi lebih nyata dan siswa cepat memahami pembelajaran yang diajarkan, serta mengetahui kegiatan ekonomi di lingkungan sekitar dan manfaat dari alam sekitar. Selain itu siswa juga terus dihimbau untuk selalu menjaga lingkungan di sekitarnya sehingga mampu menjaga dan berprilaku yang baik terhadap lingkungan.

Dengan menerapkan pendekatan saintifik berorietasi Tri Hita Karana, maka tujuan pembelajaran dapat tercapai dan memberikan pengaruh terhadap kompetensi pengetahuan

Pengaruh Pembelajaran Berpendekatan Saintifik Berorientasi Tri Hita Karana Terhadap Kompetensi Pengetahuan IPS Siswa Kelas IV 
Km. Krisna Handayani, Ign. I Wayan Suwatra, D. Putu Parmiti. (2018). Jurnal Pendidikan Multikultural Indonesia. Vol. 1 (2) pp. 85-95.

IPS siswa. Saat proses pembelajaran, guru hanya berperan sebagai fasilitator dan membimbing pada saat siswa mengalami kesulitan, selain itu guru juga berperan sebagai motivator agar siswa lebih aktif dan semangat dalam mengikuti proses pembelajaran.

Penjelasan diatas didukung oleh pendapat Kurniasih dan Sani (2014:29) yang menyatakan bahwa.

Pendekatan saintifik adalah proses pembelajaran yang dirancang sedemikian rupa agar peserta didik secara aktif mengkonstruk konsep, hukum atau prinsip melalui tahaptahapan baik itu berupa mengamati, merumuskan masalah mengajukan atau merumuskan hipotesis, mengumpulkan data dengan berbagai teknik, menganalisis data, menarik kesimpulan, dan mengomunikasikan konsep, hukum, atau prinsip yang ditemukan.

Sejalan dengan teori diatas Setiawan (2016) menyatakan bahwa "Pendekatan saintifik merupakan suatu pendekatan ilmiah, yang dirancang sedemikian rupa agar peserta didik secara aktif mengkonstruk kompetensi sikap, pengetahuan, dan keterampilan melalui tahapan mengamati, menanya, mengumpulkan informasi, menalar dan mengomunikasikan". Penelitian yang dilakukan Setiawan tentang penerapan pendekatan saintifik berhasil diterapkan di kelompok eksperimen. Selain itu Ariestia (2015) juga menyatakan bahwa "melalui penerapan pendekatan saintifik siswa memiliki kompetensi sikap, pengetahuan, dan keterampilan yang lebih baik". Penelitian yang dilakukan Ariestia juga berhasil diterapkan di kelompok eksperimen untuk meningkatkan kompetensi pengetahuan siswa. Pembelajaran menjadi lebih bermakna dan suasana belajar menjadi lebih harmonis apabila pendekatan saintifik diorientasikan dengan Tri Hita Karana. Menurut Putra (2019) dengan menerapkan semua nilai-nilai Tri Hita Karana di dalam proses pembelajaran akan tercipta suasana yang harmonis atau menjadikan pembelajaran yang kondusif, siswa nyaman dalam belajar dan meningkatkan pengetahuan siswa. Tri Hita Karana tidak hanya memberikan peningkatan dalam kompetensi pengetahuan siswa namun juga dapat memperbaiki karakter dan perilaku siswa. Hasil penelitian Putra menyatakan bahwa dengan menerapkan pembelajaran berorientasi Tri Hita Karana dapat meningkatkan kompetensi pengetahuan siswa.

Jadi dapat disimpulkan bahwa pendekatan saintifik berorientasi Tri Hita Karana merupakan proses pembelajaran yang dirancang sedemikian rupa agar peserta didik secara aktif mengkontruk kompetensi sikap, pengetahuan, dan keterampilan melalui tahapan mengamati, menanya, mengumpulkan informasi, menalar dan mengkomunikasikan dengan mengaitkan pembelajaran dengan lingkungan di sekitar siswa sehingga kompetensi pengetahuan siswa menigkat.

Adapun yang menjadi kelemahan dalam penelitian ini yaitu tipisnya perbedaan pelaksanaan pembelajaran di kelompok eksperimen yang dibelajarkan dengan pendekatan saintifik berorientasi Tri Hita Karana denga kelompok kontrol yang dibelajarkan dengan pendekatan saintifik yang tidak berorientasi Tri Hita Karana yang biasa diajarkan oleh guru di sekolah tersebut. Namun pembelajaran di kelompok eksperimen lebih menekankan tentang penerapan nilai-nilai yang terkandung dalam Tri Hita Karana, guru lebih intensif dalam menerapkan nilai hubungan manusia dengan Tuhan, manusia dengan manusia, dan manusia dengan lingkungan saat proses pembelajaran. Sedangkan di kelompok kontrol guru hanya mengajar biasa tanpa menekankan nilai-nilai Tri Hita Karana saat proses pembelajaran. 
Km. Krisna Handayani, Ign. I Wayan Suwatra, D. Putu Parmiti. (2018). Jurnal Pendidikan Multikultural Indonesia. Vol. 1 (2) pp. 85-95.

\section{SIMPULAN}

Adapun simpulan yang dapat dikemukakan dari penelitian ini yaitu terdapat pengaruh yang signifikan pembelajaran berpendekatan saintifik berorientasi Tri Hita Karana terhadap kompetensi pengetahuan IPS siswa kelas IV SD Kecamatan Bangli Kabupaten Bangli. Hasil pengujian hipotesis membuktikan bahwa thitung $>$ ttabel $(43,44>1,68023)$ yang diuji pada taraf signifikan $5 \%$ dengan $\mathrm{db}=43$. Dengan demikian, pendekatan saintifik berorientasi $T r i$ Hita Karana berpengaruh terhadap kompetensi pengetahuan IPS siswa kelas IV SD gugus II Kecamatan Bangli Kabupaten Bangli.

Berdasarkan hasil penelitian yang telah dilakukan, saran yang dapat disampaikan adalah yang pertama, siswa disarankan agar lebih aktif dan semangat dalam mengikuti pembelajaran yang diberikan guru, sehingga dapat meningkatkan kompetensi pengetahuan di setiap mata pelajaran. Kedua, engan dilaksanakannya penelitian ini, guru disarankan agar lebih berinovasi dan kreatif untuk memberikan fasilitas seperti sumber belajar ataupun media pembelajaran. Ketiga, hasil penelitian ini agar dapat digunakan oleh kepala sekolah sebagai acuan untuk membimbing guru-guru dalam melaksanakan pembelajaran dengan mengembangkan pendekatan saintifik seperti mengorientasikannya dengan Tri Hita Karana untuk meningkatkan kompetensi pengetahuan siswa. Keempat, dengan dilakukannya penelitian ini, kepada peneliti lain disarankan agar dapat digunakan sebagai acuan keputusan untuk melakukan penelitian dalam variabel yang sama ataupun variabel yang berbeda. Sebelum melaksanakan penelitian sebaiknya diadakan pre-test terlebih dahulu, agar perbedaan hasil belajar siswa lebih jelas terlihat.

\section{DAFTAR PUSTAKA}

Adiwiguna, I Wayan, dkk. 2016. "Model Pembelajaran Role Playing Berbasis Pendekatan Saintifik Berpengaruh Terhadap Penguasaan Kompetensi Pengetahuan IPS". EJournal Mimbar PGSD Universitas Pendidikan Ganesha. Vol. 4, No. 1.

Ani, Ni Kd Kisri, dkk. 2017. "Pengaruh Model Pembelajaran Time Token Berbasis Tri Hita Karana Terhadap Hasil Belajar IPS Siswa Kelas V". E-Journal Mimbar PGSD Universitas Pendidikan Ganesha. Vol. 5, No. 2.

Apriliani, Ni K Winda, dkk. 2016. "Pendekatan Saintifik Berbantuan Media Gambar Berseri Berpengaruh Terhadap Keterampilan Menulis Siswa Kelas I SD”. E-Journal Mimbar PGSD Unibersitas Pendidikan Ganesha. Vol. 4, No. 1.

Ardiantari, Ni L. Pt. Novi, dkk. 2015. "Penerapan Pendekatan Saintifik dengan Penilaian Proyek untuk Meningkatkan Kemampuan Pemecahan Masalah dan Hasil Belajar Pengetahuan Matematika Tema Cita-Citaku Siswa Kelas IVB SD Negeri 8 Pemecutan". E-Journal Mimbar PGSD Universitas Pendidikan Ganesha. Vol. 3, No. 1.

Astianawan, I Pt, dkk. 2016. "Penerapan Pendekatan Saintifik Berbasis Penilaian Portofolio Dapat Meningkatkan Kemampuan Pemecahan Masalah Dan Penguasaan Kompetensi Pengetahuan Matematika Siswa Kelas III". E-Journal Mimbar PGSD Universitas Pendidikan Ganesha. Vol. 4, No. 1.

Dewi, Luh Pt Ariestia, dkk. 2015. "Penerapan Pendekatan Saintifik dengan Penilaian Proyek untuk Meningkatkan Kemampuan Berpikir Kreatif dan Hasil Belajar Pengetahuan Matematika Siswa Kelas IV SD". E-Journal Mimbar PGSD Universitas Pendidikan Ganesha. Vol. 3, No. 1.

Indrawan, I Wy Astra, dkk. 2017. "Pengaruh Model Pembelajaran Think Talk Write Berbasis Tri Hita Karana Terhadap Kompetensi Pengetahuan IPS". E-Journal Mimbar PGSD Universitas Pendidikan Ganesha. Vol. 5, No. 2. 
Km. Krisna Handayani, Ign. I Wayan Suwatra, D. Putu Parmiti. (2018). Jurnal Pendidikan Multikultural Indonesia. Vol. 1 (2) pp. 85-95.

Megawati, Dewa Ayu Tri, dkk. 2015. "Penerapan Pendekatan Saintifik dengan Penilaian Proyek untuk Meningkatkan Kemampuan Penalaran dan Hasil Belajar Pengetahuan Matematika Siswa Kelas IVB SD". E-Journal Mimbar PGSD Universitas Pendidikan Ganesha. Vol. 3, No. 1.

Priyanti, Andrie Eka, dkk. 2016. "Pendekatan Saintifik Berbasis Problem Based Learning Berpengaruh Terhadap Hasil Belajar Pengetahuan Matematika Siswa Kelas IV SD Gugus P.B. Sudirman Denpasar Tahun Ajaran 2015/2016". E-Journal Mimbar PGSD Universitas Pendidikan Ganesha. Vol. 4, No. 1.

Putra, I G. N. Pt. A. Laksana, dkk. 2019. "Pengaruh Model SFAE Berorientasi Tri Hita Karana Terhadap Hasil Belajar IPA". E-Journal Mimbar PGSD Universitas Pendidikan Ganesha. Vol. 3, No. 2.

Putra, I Wayan Weda Gustana, dkk. 2016. "Pengaruh Model Pembelajaran SAVI Bermuatan Tri Hita Karana Terhadap Hasil Belajar IPA Siswa Kelas IV'. e-Journal Mimbar PGSD Universitas Pendidikan Ganesha.Vol. 4, No.1.

Setiawan, I Kd, dkk. 2016. "Penerapan Pendekatan Saintifik Berbasis Kearifan Lokal Untuk Meningkatkan Penguasaan Kompetensi Pengetahuan PKn Siswa Kelas VB SDN 1 Ubud Tahun Ajaran 2015/2016". E-Journal Mimbar PGSD Universitas Pendidikan Ganesha. Vol. 4, No. 1.

Susanto, Ahmad. 2013. Teori Belajar Dan Pembelajaran Di Sekolah Dasar. Jakarta: Kencana Prenada Media Group.

Sutoyo. 2011. Pendidikan Kewarganegaraan Untuk Perguruan Tinggi. Yogyakarta: Graha IImu.

Widariwati, N Putu, dkk. 2016. "Pendekatan Saintifik Berorientasi PBL Berpengaruh Terhadap Hasil Belajar Pengetahuan PKn Siswa Kelas V SD”. E-Journal Mimbar PGSD Universitas Pendidikan Ganesha. Vol. 4, No. 1. 